\author{
DEPARTMENT OF THE INTERIOR \\ UNITED STATES GEOLOGICAL SURVEY
}

\title{
TRANSCONTINENTAL GEOPHYSICAL SURVEY $\left(35^{\circ}-39^{\circ} \mathrm{N}\right)$ MAGNETIC MAP FROM $100^{\circ}$ TO $112^{\circ} \mathrm{W}$ LONGITUDE \\ By
}

Isidore Zietz and John R. Kirby
MISCELLANEOUS GEOLOGIC INVESTIGATIONS
MAP I-533-A

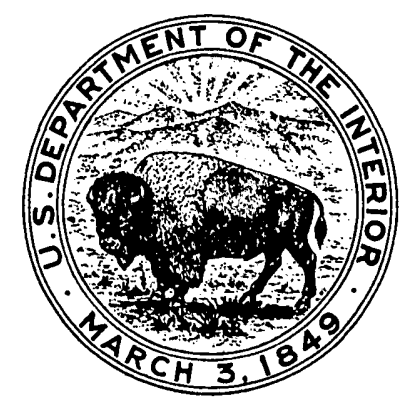

A CONTRIBUTION TO THE UPPER MANTLE PROJECT 